\title{
当院での結核性脊椎炎の診断と治療
}

国立療養所福岡東病院整形外科
三尾母
英

福岡豊栄会病院整形外科

島内卓

\section{Diagnosis and Treatment of Tuberculous Spondylitis}

by

\author{
Hideyuki Miomo, Sinsuke Matsumoto, Youichirou Iwamatsu, \\ and Keizou Akagi \\ Department of Orthopedic Surgery, National Fukuoka Higashi Hospital
}

Takashi Shimauti

Department of Orthopedic Surgery, Fukuoka Houeikai Hospital

\begin{abstract}
Twenty-nine patients with a diagnosis of tuberculous spondylitis were reviewed regarding clinical features, radiographic findings and surgical outcome. $14(48 \%)$ patients were aged in their fifties and sixties. Neurologic complications had occurred in $9(31 \%)$ patients, 8 of whom could not walk. In five patients, the neurologic deficit almost recovered to normal. On radiographic evaluation, bony destruction over the half of the vertebral body was apparent in $29(88 \%)$, but bony bridge and sclerotic changes in the involved vertebrae were not present in non-treated cases at admission. Tomography can be useful for detection of subtle changes in the vertebral body. We operated on 29 cases ( 33 lesions), of which 18 lesions were treated by curretage and anterior spinal fusion, 14 received ahterior spinal fusion and posterior instrumentation combined, one received only posterior fusion with instrumentation. All cases with anterior spinal fusion and bone graft achieved stable union with satisfactory results.
\end{abstract}

Key words : Tuberculous spondylitis (結核性脊椎炎), Tomography (断層撮影), Bony bridge (骨橋), Posterior instrumentation（後方固定用インストルメント）

はじめに

奉椎炎症性疾患の中で結核性脊椎炎は戦後激減した とはいえ，ひとたび起これば麻痺の発生や多椎間䍜患 となることが少なくなく軽視できない疾患である.し かしその診断にあたって化膿性脊椎炎との鑑別に悩む 症例に遭遇することも珍しくはなく，正しい診断の必 要性を実感させられる. また脊椎カリエスに対する手 術的治療の有効性は広く認識されるところとなったが,
最近は後方インストルメントを併用した報告む多い. 今回我々は当院での近年の結核性脊椎炎症例の臨床像, 臨床検査, X線写真等の特徴について, また手術治療 について検討したので報告する.

\section{症例}

1984 年から 1995 年までの 12 年間に当院で治療を 行った結核性脊椎炎は 29 例で男性 13 例, 女性 16 例 であり全例手術的治療を行った. 術後経過観察期間は 
最低 9 力月, 最高 10 年であった. 入院時年齢は 22 才 から 80 才まで平均 51.6 才であった. 29 例中椎体病巣 の細菌学的, 病理学的検査で脊椎カリエス之診断され たのは 24 例であった。他は肺結核の合併, カリエス の既往がありX線, 臨床検査等もあわせ総合的に判断 した.

\section{結果}

\section{臨床像}

\section{1. 年齢分布}

50 代 6 例， 60 代 8 例とこの 2 つの年代が多かった が，20 代 5 例でここにも小さなピークがあった（表 $1)$.

\section{2. 罹患椎体部}

罹患椎体部位は胸椎 16 , 腰椎 13 , 頸椎 1 で胸椎部 䍜患が最む多かったが，29 例中 4 例は別々に 2 力所 の䍜患部を有していた．胸椎の中では第 8 から 12 胸 椎に病巣が集まっていた。腰椎では第 3 腰椎が 10 と 最む多いが幅広く分布していた（表 2 ）.

\section{3. 他の結核合併}

脊椎カリエス以外の結核病巣は肺，粟粒結核が 24 例 $82 \%$ と高率でそのほかには脳結核腫，関節結核，

\section{表 1}

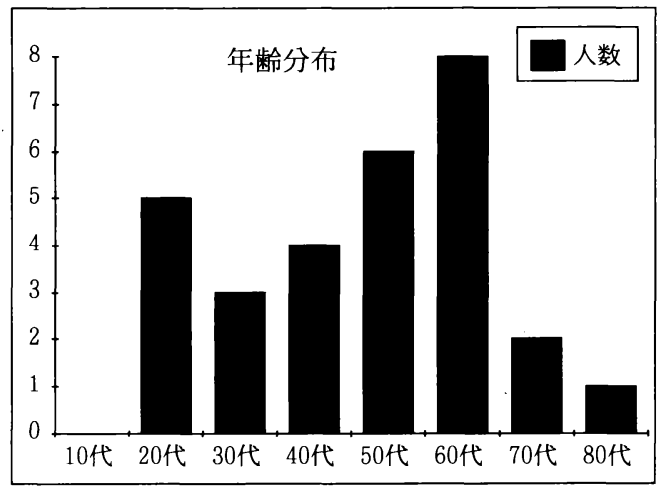

表 2 䍜患椎体

\begin{tabular}{lrl}
\hline \hline 頝椎 & 1 & \\
䅡胸椎 & 1 & \\
胸椎 & 16 & \\
胸腰椎 & 1 & \\
腰椎 & 13 & \\
腰仙椎 & 1 & \\
& & 計 33 部 位 \\
\hline
\end{tabular}

結核性髄膜炎がそれぞれ 1 例ずつであった。他に結核 病巣がなくて脊椎カリエスのみの者は 4 例であった。

\section{4. 麻疸}

いわゆる Pott 麻瘏は 9 人に見られ歩行不可の者は 8 例, 下肢の軽度の麻痺が 1 例であった。これは全体

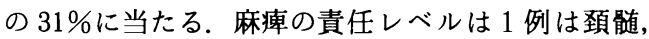
8 例は胸䯣レベルであった，麻瘏の手術による回復状 況はFrankel の C から E が 5 人，C から D が 3 人， $\mathrm{D}$ から $\mathrm{E}$ が 1 人で歩行不能な 8 人中 5 人がほぼ正常 な歩行状態に回復していた。

臨床検查

入院時の血液学的検查を CRP, 白血球, 血沈の 3 項目で調べると平均値で CRP は 2.88（0.1 7.58）白 血球は 6090 (2200 10100) 血沈は $57 \mathrm{~mm} / \mathrm{h} （ 5$ 〜 121）であった．白血球数の最高 10100 は痔ろう合併 していた者でそれ以外はすべて 1 万以下であった.

画像的所見

29 例全例椎体を主病巣部としていたが， 1 例のみ 椎弓にも病変が存在していた.

\section{1. 罹患椎体数}

単純X線, Tomography で認められた椎体破壊の ある罹患椎体の数は 1 椎体 1 例, 2 椎体 14 例, 3 椎 体 6 例, 4 椎体 3 例, 5 椎体 1 例, 6 椎体 3 例, 7 椎 体 1 例で平均 3.1 椎体であった。

\section{2 . 椎体病巣部所見}

椎体破壊度または椎体内の空洞形成の大きさを椎体 高の割合で見てみると $1 / 2$ 以上の者が 29 部， $88 \%$ と かなり高率であった．椎体間隙は 26 部，79\%で明ら かに狭小化していた，椎体両側の軟部陰影の腫大の膿 瘍像は 23 部 70\%に見られたが，特に腰椎部では全腰 椎罹患 15 部中 14 部，93\%に腫大陰影が見られ CT で もその 14 部に大腰筋内膿場を確認した。椎体間に島 状，粒状に存在する硬化像の腐骨陰影は 12 部位， 41 \%に見られた。骨橋，骨棘は 5 部，15\%で見られたが 3 部はすでに化学療法が開始され $2,8 ， 10$ 力月が

\section{表 3 X線所見}

$\begin{array}{lr}\text { 椎体破壊 } 1 / 2 \text { 以上 } & 29(88 \%) \\ \text { 椎間間隙狭小化 } & 26(79 \%) \\ \text { 膿瘍陰影 } & 23(70 \%) \\ \text { 腐骨陰影 } & 12(41 \%) \\ \text { 骨橋, 骨梀形成 } & 5(15 \%) \\ \text { 硬化像 } & 3(9 \%) \\ \text { 椎弓根破壊 } & 0\end{array}$



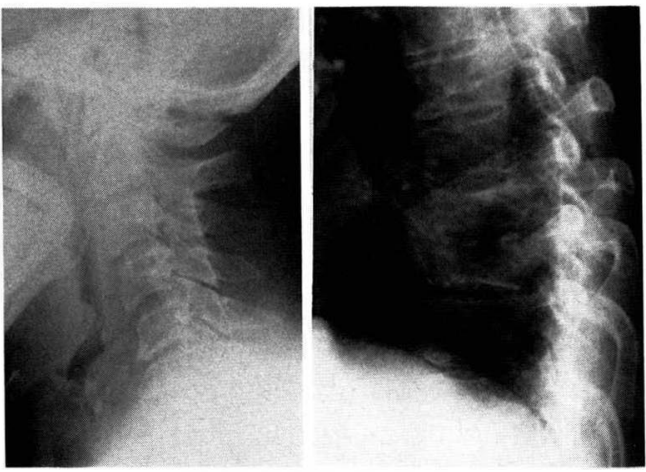

図1 $\mathrm{C}_{6}$ 椎体高やや低くなっている程度で破壊は 明らかでない。

$\mathrm{T}_{8.9}$ 9 椎体間腔の狭小化と骨破壊を認める。

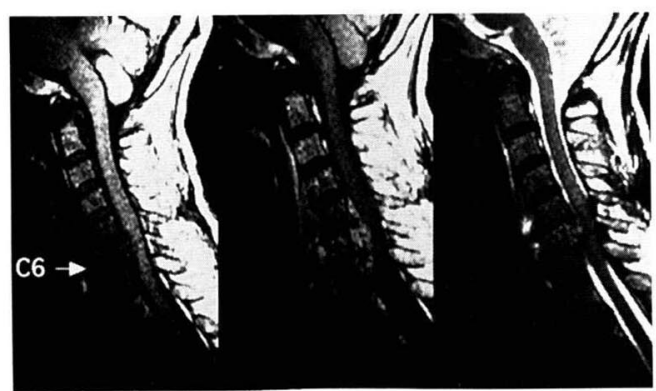

図 2 MRI 像, 左: $T_{1 w}$ 中: $G d$ enhance 右: $\mathrm{T}_{2 \mathrm{w}}$

$\mathrm{C}_{6}$ は $\mathrm{T}_{1 \mathrm{w}}$ で low, Gd エンハンスで明らかな rim enhancement, $\mathrm{T}_{2 \mathrm{w}}$ で high と low のモ ザイク状の像を呈する。

経過し残り 2 部は再発であった. 椎体破壊縁の硬化像 は 3 部に見られた。しかし 2 例には化学療法が開始さ れていて 5,10 力月が経過し，他の 1 例は再発例で あった．椎弓根破壊例はなかった（表 3 ）

\section{MRI 像}

MRI は 6 例に行われていたが，おおむね $\mathrm{T}_{1 \text { w }}$ では 低信号, $\mathrm{T}_{2 \mathrm{w}}$ では高信号と低信号の混在像を示した. CT 像と照らし合わせてみると膿瘍は高信号, 腐骨は 低〜無信号として表されていた. Gd での造影施行例 は2 例しかないが Sharif のいういわゆる rim en hancement が 2 例とも見られた。

\section{手術治療}

29 例全例に手術的治療を行った。手術は普通 3 週 から 3 力月間化学療法を行ってから施行したが, 麻痺 例では早期に手術を行った。抗結核剂は原則として 3
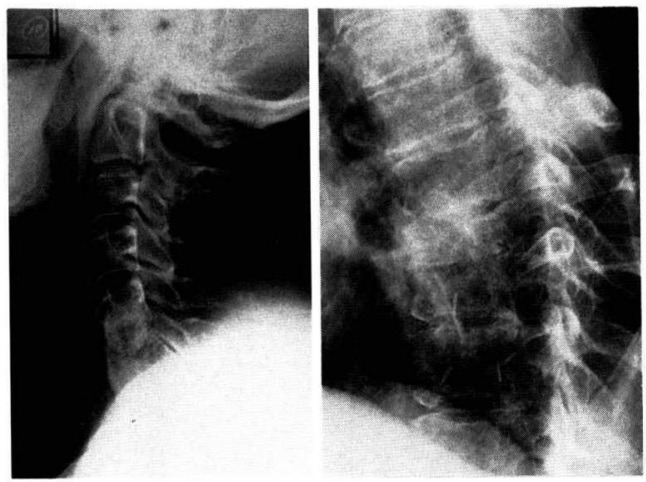

図 3 左 : $\mathrm{C}_{5-1}$ の前方固定後 右 : $T_{7-10}$ の前方固定後 ほぼ骨癒合が得られ歩行も良好なまでに回復 した.

剤（INH．REP. SM or EB）併用を行った。術式は 前方からの病巣郭清, 前方固定を行った群が 18, 前 方固定に後方インストルメントを併用した群が 14, 後方インストルメントのみによる固定が 1 部あった. インストルメントの種類は $\mathrm{CD}$ が 8 ，ハリントンが 5 , Luque が 1 であった．術後は前方固定群は $2 \sim 3$ 力 月間ギプスベッド上安静，インストルメント併用群は $1 \sim 2$ 力月で歩行開始とした．前方固定をした全例に ほぼ骨癒合を得られ再発やインストルメントの感染は 1 例むなかった，前方固定単独群とインストルメント 併用群間で局所後弯度の矯正損失を術直後と最新のも のとを比べて求めると前方固定群は平均 $3.9^{\circ}$ の損失, 併用群は平均 $2.5^{\circ}$ の損失で併用群の方が損失は少なかっ たが単独群との有意差は認められなかった。

術後合併症

術後合併症は 4 例，13.8\%に認められたが内訳は乳 び胸 1 , 無気肺 1 , 後方インストルメ.ント後の EHL の低下 1 , 輸血後肝炎 1 であった.

$$
\text { 症例 }
$$

症例 169 才 女性 肺結核 T8，9 カリエスの 診断で他院より紹介され入院. 両下肢の麻㾇があり下 肢筋力は MMT で 0 ～ 2 で膝立ても不可能であった. また入院時より次第に増強する頝部から右上肢への放 散痛があり諸検査で $\mathrm{C}_{6}$ カリエスむ存在する事が判明 した，右上腕三頭筋，手関節背屈筋力む 2,3 へ低下 していた. 


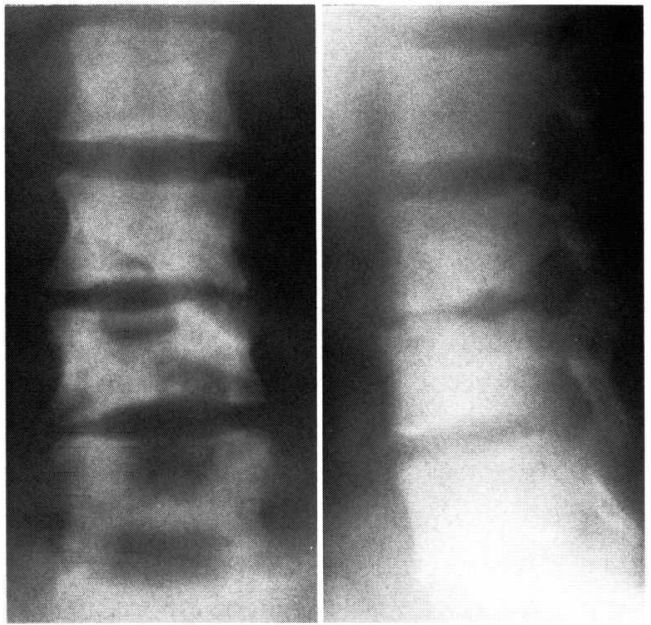

図 4 Tomo で $L_{2}, 3,4$ 椎体の空洞形成がはっきり と認められる。

画像所見 X線写真では $T_{8,9}$ に骨破壊を認めるが, 頚椎では $\mathrm{C}_{6}$ 圧迫骨折様所見しかわからない（図 1 ). MRI では頝椎で $\mathrm{T}_{1} \mathrm{~W}$ で low, $\mathrm{T}_{2} \mathrm{~W}$ では高信号と低 信号がモザイク状に混在した像を, Gd エンハンス像 では無信号の物の周用にエンハンスされた高信号域 (rim enhancement) が見られる.（図 2) 胸椎でむ ほぼ同様の所見と胸髄への強い圧迫像を認めた.

まず胸椎の病巣郭清と $\mathrm{T}_{7 \sim 10}$ の前方固定術を行い, 9 日後に $C_{5 \sim 7}$ の前方固定術を施行した. 術後は頭部 から腰部までの固定装具にて約 2 力月間安静としたが ベッドサイドリハは術後早期から開始した. 麻痺は順 調に改善し現在下肢のしびれはあるも運動はほぼ正常 に回復し歩行状態, 上肢機能とも良好である（図 3 ).

症例 224 才男性 $\mathrm{L}_{3}, 4,5$ カリエスならびに肺結 核. 他院で喀痰から結核菌 G3 号検出され紹介入院.

画像所見 Tomography で $\mathrm{L}_{3}, 4,5$ の椎体終板近 くに大きな空洞形成を認める. 両側大腰筋内に大きな 膿瘍も見られた（図 4 ）.

手術は始めに $\mathrm{L}_{1} \sim \mathrm{S}_{1}$ の $\mathrm{CD}$ による後方固定術を行 い, 2 週間後に $\mathrm{L}_{3} \sim_{5}$ の前方固定術を行った. 左側 進入で経椎体的に右側の膿も吸引した. 良好な骨癒合 が得られ治癒した（図 5 ).

\section{考察}

結核性脊椎炎の年代別発生数は昭和 30 年, 40 年代 の報告が 30 才代，40才代にピークがあるのに対し近

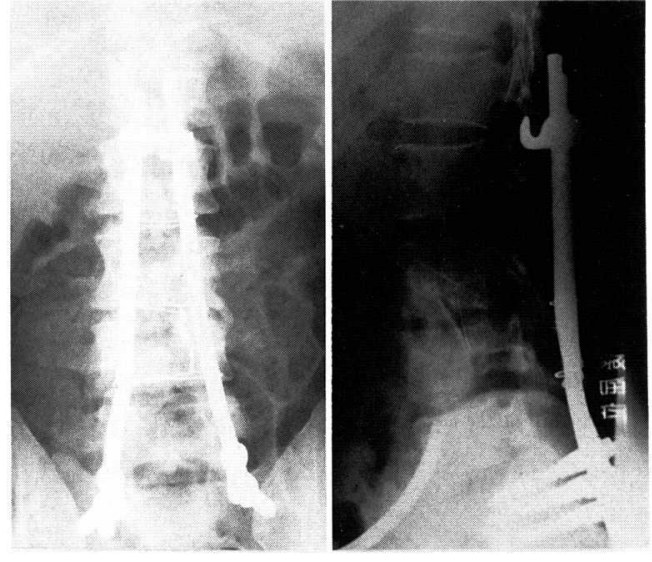

図 $5 \mathrm{~L}_{3-5}$ の前方固定術と $\mathrm{L}_{1} \sim \mathrm{S}_{1}$ の CDI による 後方固定を併用し，良好な骨癒合を得た。

年では我々の報告のごとく 50 ないし 60 才代にピーク があるという報告が多い。これは高齢者人口の増加と 宿主側の免疫力低下者が高歯者になると増加してくる 事が関係するのであろう。当院では肝硬変が 2 人, 糖 㽷病 1 人, Wegener 肉芽腫症でステロイド使用者が 1 人, の 4 人に免疫力低下の存在があると思われたが いずれも 59 才以後の年㱓であった.

椎体䍜患高位は $\mathrm{T}_{8 \sim 11}, \mathrm{~L}_{2,3}$ に眻患椎が多く頚椎や 上位胸椎には少なかった．血液学的検查ではその值は 入院時期により少しは異なると思われるが平均值で WBC は 6090, CRP 2.88, 血沈 $57 \mathrm{~mm} / \mathrm{h}$ で軽度から 中等度の炎症といえる. 血沈と CRP は診断だけでな く結核治療をしていくうえでの目安となるので定期的 なチェックが必要である.

結核性脊椎炎による脊䯣麻㾝は歩行不能な程度の麻 痺が 8 人存在したが手術後に 5 人はほとんど正常な歩 行に回復した. 手術の際注意する点は, 圧迫している 腐骨や壊死組織は切除し膿は吸引し洗浄するが肉芽の ためPLL が温存されているかどうかが判定しづらい 事があるので後方の肉芽は切除にあまり固執せず洗う 程度にし疌髄にダメージを与えないことが大事である.

脊椎力リエスのX線像では $1 / 2$ 椎体高以上の椎体破 壊が 88\%，椎体間隙の狭小化が 79\%，膿瘍陰影が 70 $\%$ 之高率だった，逆に骨棘，骨橋形成や硬化像は 15 \%，9\%にしか存在せず，すべて再発例または化学療 法による治療中の症例で未治療群には骨橋, 硬化像之 もに見られなかった。この点は化膿性脊椎炎が自然経 
過で発症してから $1 \sim 3$ 力月程度で骨硬化, 骨橋, 骨 棘形成が起こるのと比べ ${ }^{5}$ 対照的だといえる．なお腰 背部痛が出現してから手術までの期間が当院では平均 9.2 力月（ $3 \sim 18$ 力月）だった。 また骨破壊も化膿性 脊椎炎が多くは $1 / 2$ 椎体高以内之言われる ${ }^{4)}$ が, カリ エスでは 8 割以上は $1 / 2$ 椎体高以上の破壊があった.

以上の臨床像, 臨床検査, X線像から結核性脊椎炎の 特徵としては軽度から中等度の炎症反応で血沈は 2 け た, CRP は最大 8 以下, $1 / 2$ 椎体高以上の空洞形成 や骨破壊があり, 特に腰椎で大腰笳内の膿傷を有する, 骨橋や骨硬化がない，といった所見が見られれば脊椎 カリエスと考えてほぼ間違いないと考えられる．X像 診断では単純写だけでなく Tomography をとること が大事である. Tomography で初めて椎体内の空洞 や骨橋がわかることが多いし脊椎カリエスの早期発見, 化膿性脊椎炎との鑑別には欠かせない，結核は病理学 的に炎症初期の浸出性病变の時は乾酪壊死, 類上皮細 胞などの特徵的な組織所見がなくまた膿もなくこの時 期のカリエスの診断は生検を行っても困難であるが, 脊椎カリエスの早期は痛みが軽いせいか出会う機会が 少ないようである．脊椎カリエスの早期診断には微細 な骨変化を描出できる MRI ${ }^{3), 6)}$ Tomography が有効 と思われるが診断し難い場合は経過を追うことにより 特徴的な所見が出てくるので観察を十分に行うことが 大切であろう. 最近は弱毒菌による化膿性脊椎炎との 鑑別に困るような症例に遭遇することも少なくない。

結核性脊椎炎に対する前方進入による郭清, 固定術 は Hodgson ${ }^{2)}$ により始められ本術式により良好な成 績が各施設で報告されているが最近はこの前方固定術 に加えて後方インストルメントを併用するといった報 告が散見される ${ }^{7}$. 我々屯前方固定術を中心に行って いるが症例により後方インストルメントを併用してい る. 前方法十後方法は 14 例で骨癒合も良好で感染も なかった，適用としては多椎間固定術の時, 強い後弯 変形を矯正する時, 早期離床が必要な合併症を有する ときなどが挙げられる11. 術後は早期離床ができ管理 あしやすくなる，しかし手術侵襲が大きくなり，出血 が多くなること, 感染の危険性が新たにでてくること,
罹患椎体を避けてフック，スクリューを入れるので前 方固定範囲よりも固定椎間がさらに広くなり特に腰椎 では可動椎間の減少が後の腰痛の発生原因となりうる 事などを十分認識しておく必要がある.

\section{ま と め}

1. 最近 12 年間に経験した 29 例の結核性脊椎炎に ついて検討した.

2. 50 才， 60 才代が最も多かったが 20 才代にも第 2 のピークがあった.

3 . 麻瘒は 9 例, $31 \%$ に見られ, 歩行不能な 8 人中 5 人はほぼ正常な歩行状態に回復した.

4.X線的には椎体の破壊, 空洞形成が椎体高の $1 / 2$ 以上を占める例が $88 \%$, 傍脊椎の膿瘍陰影が腰椎 部では $93 \%$ と高率に見られた。逆に骨橋や骨硬化像 は未治療の状態で見られたものはなかった.

5. 手術的治療を全例に行ったが 18 部は前方固定 のみ, 14 部は前方固定に後方 inatrument を併用し たが全例にほぼ骨癒合を得られた。

\section{参考文 献}

1）秋山徹ほか：神経麻疸を合併した結核性脊椎炎に対 する Harrington instrumentation. 西日脊会誌 $11: 97$ $101,1985$.

2) Hodgson, A. R., Yau, A., et al., : Clinical Study of 100 Consecutive Cases Pott's Paraplegia. Clin. Orthop. 36 : 128-150, 1964.

3）樫本 修ほか：化膿性脊椎炎と脊椎カリエスの鑑別診 断と MR 像の病理組織的学解釈. MB Orthop. 9:1527, 1996.

4）国分正一ほか：化膿性脊椎炎，臨整外，13：307-317, 1978.

5）下出真法ほか：化膿性脊椎炎の臨床像一結核性脊椎炎 との比較一, 臨整外. $13: 317-322,1978$.

6) Smith, A. S., et al., : MR Imaging Characteristics of Tuberculous Spondylitis vs Vertebral Osteomyelitis. AJNR. 10 : 619-625, 1989.

7) 辻 正二ほか: Cotrel-Dubousset Instrumentation を併用した結核性脊椎炎の 3 手術例。整・災外. 36 ： 727-731, 1993. 